\title{
FENOMENA PERNIKAHAN ANAK DI SUMENEP MADURA
}

\author{
Jamilah, Raudlatun \\ STKIP PGRI Sumenep, Indonesia \\ E-mail: jamilah@stkippgrisumenep.ac.id
}

\begin{abstract}
In the current era of globalization, early marriage still often occurs. Factors causing early marriage are economic factors, educational factors, parental factors, and pregnancy factors outside of marriage. Early marriage also has physical and psychological effects. As for physically covering the household economy because at the age of adolescence is still unable to provide for his own family, while economic factors are factors that can prosper the household, besides that there is also a risk of pregnant women, in adolescence are generally a danger to health because if a person is under age 20 years of pregnancy results in death of mother and child or can experience premature childbirth. While the psychological impact of early marriage there is a severe depression which is a symptom that causes a person to become a private person who is not sociable, and there are conflicts that lead to divorce because of emotions in adolescents who are unstable lead to prolonged conflict in couples who marry at an early age which results in divorce.
\end{abstract}

Keywords: phenomenon; child marriage; Sumenep

Abstrak. Di era globalisasi saat ini pernikahan dini masih kerap terjadi. Faktor-faktor penyebab terjadinya pernikahan dini adalah faktor ekonomi, faktor pendidikan, faktor orang tua dan faktor hamil di luar nikah. Pernikahan dini juga mempunyai dampak secara fisik maupun psikologis. Adapun secara fisik meliputi ekonomi rumah tangga karena pada usia remaja masih belum bisa menafkahi keluarganya sendiri, sementara faktor ekonomi merupakan faktor yang dapat mensejahterakan rumah tangga, selain itu ada pula resiko ibu hamil, di usia remaja umumnya bahaya bagi kesehatan karena apabila seorang yang berusia dibawah 20 tahun hamil mengakibatkan kematian pada ibu dan anak atau dapat mengalami melahirkan sebelum waktunya. Sedangkan dampak pernikahan dini secara psikologis terdapat depresi berat yaitu suatu gejala yang mengakibatkan seseorang menjadi pribadi yang tertutup dan tidak mudah bergaul, adapula konflik yang berujung perceraian karena emosi pada remaja yang tidak sabil mengakibatkan terjadinya konflik secara berkepanjangan pada pasangan yang menikah di usia dini yang mengakibatkan terjadinya perceraian.

Kata Kunci: Fenomena; Pernikahan Anak; Sumenep

Permalink/DOI: https://doi.org/10.15408/harkat.v15i1.13437 


\section{Pendahuluan}

Pernikahan merupakan hal yang penting, karena dengan pernikahan seseorang akan memperoleh keseimbangan hidup baik secara biologis, psi kologis maupun secara sosial. Secara biologis, kebutuhan seksual terpenuhi. Secara psikologis, kemaatangan mental dan stabilitas emosi, juga turut menentukan kebahagaiaan hidup berumah tangga. Usia pernikahan yang terlalu muda dapat mengakibatkan meningkatnya kasus perceraian karena kurangnya kesadaran untuk bertanggung jawab dalam kehidupan berumah tangga. Secara sosiologis, pernikahan menjadikan sepasang lakilaki dinilai sah sebagai pasangan suami- istri dan sah secara hukum

Pernikahan dini yaitu menikah dalam usia remaja atau muda. Sedangkan Pernikahan dini menurut Islam adalah pernikahan yang dilakukan orang yang belum baligh (mimpi basah) bagi laki-laki atau belum mendapat menstruasi pertama bagi perempuan. Sebagian ulama memperbolehkan pernikahan di bawah umur, dengan dalil: pertama, mengikuti sunnah rasul karena sejarah telah mencatat bahwa Aisyah dinikahi oleh Nabi Muhammad pada usia 6 tahun sedangkan Muhammad telah berusia 50an tahun; kedua, per nikahan dini dinilai dapat mempertahankan norma-norma agama berupa menghindarkan pasangan muda- mudi dari dosa akibat pergaulan bebas dan perzinaan, sehingga sebagian orang mengartikan bahwa tujuan per nikahan adalah menghalalkan hubungan seks (.http://www.isadanislam.com/ulasan-beritaagama/145). Dahulu kawin muda dianggap lumrah dan biasa terhjadi di masyarakat Sulaiman (2012) mengatakan bahwa di Jawa Timur perkawinan pada usia di bawah umur terbanyak adalah di Madura, bahkan hampir merata di daerah Sumenep hampir mencapai 60 persen dari total penduduk. Dalam masyarakat Madura proses pernikahan dini sudah dikenal sejak lama, bahkan sudah menjadi bagian dari 'tradisi' tan pengantanan. Meskipun pada awalnya tradisi ini merupakan bagian dari proses permainan anak Sumenep di saat mekarnya kembang melati atau di saat musim nemor. Permainan anak ini diberengi dengan musik dan bernyanyi bersama dan di arak keliling kampong anak tersebut. Tradisi menikahkan anak dalam usia berkisar 13 tahun bagi perempuan atau masih SD dan 15 tahun masih SMP. Bahkan bisa juga terjadi pada bayi yang baru lahir. Terjadinya pernikahan dini di Sumenep khususnya di dasarkan oleh beberapa faktor.

Hal ini sesuai dengan penelitian yang dilakukan oleh (Subulah dan Jannah, 2012) Dari segi psikologi, sosiologi maupun hukum Islam pernikahan dini terbagi menjadi dua kategori; pertama, pernikahan dini asli yaitu pernikahan di bawah umur yang benar murni dilaksanakan oleh kedua belah pihak untuk menghindarkan diri dari dosa tanpa adanya maksud sematamata hanya untuk menutupi perbuatan zina yang telah dilakukan oleh kedua mempelai; kedua, pernikahan dini palsu yaitu pernikahan di bawah umur yang pada hakekatnya dilakukan sebagai kamuflase dari moralitas yang kurang etis dari kedua mempelai. Pernikahan ini dilakukan hanya untuk menutupi perzinaan yang pernah dilakukan oleh kedua mempelai dan berakibat adanya kehamilan. Ketika terjadi fenomena pernikahan seperti ini, tampaknya antara anak dan kedua orang tua bersama-sama melakukan semacam "manipulasi" dengan cara melangsungkan pernikahan yang mulia dengan maksud untuk menutupi aib yang telah dilakukan oleh anaknya. Pernikahan dini hanyalah sepenggal realita sosial yang dihadapi masyarakat pada saat ini. ujuan pernikahan akan terwujud jika di antara kedua belah pihak sudah memiliki kesiapan biologis, psikologis dan ekonomi. Dengan kemampuan tersebut maka akan membantu terciptanya hu bungan yang harmonis, saling menolong dalam memenuhi hak dan kewa jiban, saling menasehati, saling melengkapi, dan saling menjaga antara satu dengan yang lain (to care each other). Untuk itu 
penulis bermaksud untuk membahas fenomena pernikahan anak yang ada di Madura khusunya di Kabupaten Sumenep.

\section{Pembahasan}

\section{Fenomena Pernikahan Anak di Sumenep}

Sumenep merupakan salah satu kabupaten yang ada di pulau Madura, dan berada paling ujung timur. Fenomena ataupun tradisi perkawinan anak ini terus terjadi, karena praktik perkawinan ini tidak hanya terjadi di desa Matanair, namun di beberapa desa di kecamatan Rubaru Kabupaten Sumenep juga terjadi, dengan beragam alasan.

Pernikahan merupakan ikatan lahir batin yang kuat dan kekal antara dua insan, rasa cinta kasih, kewajiban, dan untuk meneruskan keturunan bagi umat Islam. Salah satu tujuan syariat Islam adalah memelihara kelangsungan keturunan maka, Allah memberikan wadah untuk merealisasikan keinginan tersebut sesuai dengan syariat Islam yaitu melalui jalan pernikahan, (Wasman wardah Nuroniyah, 2011: 29), yang sah menurut agama, diakui oleh Undang-undang dan diterima sebagai bagian dari budaya masyarakat (Fuadudin, 1999: 4). Oleh sebab itu, pernikahan yang dilakukan oleh setiap masyarakat harus sesuai dengan ketentuan peraturan perundang-undangan dan tidak boleh menyalahi ketentuan hukum negara maupun hukum agama.

Namun masyarakat Sumenep khsusnya yang ada di desa Matanair Kecamatan Rubaru memahami nikah dengan sangat sederhana sekali, sehingga ketika anaknya selalu dekat dengan tunangannya maka mereka berdua akan dinikahkan walaupun secara usia masih belum mencukupi syarat usia nikah. Karena bagi orangtua, nikah itu adalah solusi untuk menghindari zina ataupun maksiat.

Penulis disini akan menganalisa salah satu kasus yang terjadi di desa Matanair Kecamatan Rubaru Kabupaten Sumenep, perempuan ini bernama Delly, dia dilahirkan di keluarga petani pada tahun 2002, dia juga mengenyam pendidikan SD, lalu MTs atau yang setara dengan SMP, namun ketika lulus MTs, saat dia masuk kelas X MA di Matanair, dia tunangan dengan orang Pakondang, hal ini atas keinginan orang tuanya, karena persepsi masyarakat kalau anaknya di usia yang seperti dia belum tunangan itu seperti orang yang belum laku (tak pajuh). Akhirnya dia ditunangkan dan selang beberapa bulan kemudia, karena dia sering boncengan dan sering berduaan dengan tunangannya, dia kemudian dinikahkan. Namun pernikahannya itu hanya dilakukan oleh modin desa, karena delly masih usianya 15 tahun saat dinikahkan pada tahun 2017, dan calon suaminya secara pendidikan juga belum lulus MA. Keluarganya Delly tidak meminta dispensasi pernikahan ke pengadilan agama, dengan alas an tidak tahu dan takut akan terjadi apa-apa. Dari pernikahannya, Delly sempat mengalami pendarahan, karena secara kesehatan kondisi fisiknya masih belum siap dibuahi, ketika dibawa ke rumah sakit, dia mendapat pertanyaan dan pernyataan yang sangat keras dari dokternya, ketika ditanya tentang usia menikahnya.

Saat ini pernikahan Delly itu belum mendapatkan surat nikah, karena tidak mencatatakan ke KUA, disebabkan waktu menikah usianya masih 15 tahun. Dia saat ini juga tidak punya KTP, dan KKnya masih ngumpul sama orang tuanya. Delly akhirnya putus sekolah, dan dia hanya membantu orang tuanya bertani untuk mencukupi kebutuhan hidupnya, suaminya hanya menjadi kuli bangunan. Dia bercerita bahwa dia kadang sering bertengkar dengan suaminya.

Inilah salah satu fenomena pernikahan anak yang terjadi di Matanair, kalau dianalisa penyebabnya dikarenakan anaknya takut berzina dan maksiat, padahal ini bukan solusi, malah menimbulkan dampak negative pada kesehatan dan pendidikan, kemudian kemandirian ekonominya. 
Faktor yang Mempengaruhi Terjadinya Pernikahan Usia Dini Di Kec Rubaru

\section{Budaya}

Budaya yang berbeda akan melahirkan standar masyarakat yang berbeda pula dalam berbagai aspek kehidupan, termasuk juga dalam mengatur hubungan pernikahan. Pernikahan merupakan salah satu contoh hubungan yang dapat dilihat secara adat istiadat suku setempat yang diterima serta diakui secara universal. Budaya yang berbeda akan melahirkan standar masyarakat yang berbeda pula dalam berbagai aspek kehidupan. Hasil penelitian membuktikan kuatnya tradisi dan cara pandang masyarakat, terutama di pedesaan, masih menjadi pendorong bagi sebagian anak perempuan lain.

\section{Pendidikan}

Pendidikan merupakan hal yang sangat penting bagi setiap orang, oleh karena itu pemerintah Indonesia telah merancang program wajib sekolah 9 tahun. Tetapi karena keterbatasan ekonomi yang rendah sering kali pendidikan tersebut terabaikan, karena tidak mampu untuk membeli segala perlengkapan sekolah. Dalam masyarakat di Sumenep pendidikan masih dianggap sebelah mata hal ini dapat dilihat karena banyaknya anak-anak yang hanya tamat Sekolah Dasar (SD) atau Sekolah Menengah Pertama (SMP). Kurangnya pengetahuan orang tua tentang pendidikan sehingga sering kali orang tua hanya bersikap pasrah dan menerima keputusan anaknya yang ingin putus sekolah, hal ini mengakibatkan terjadinya rendahnya tingkat pendidikan di Sumenep dan mengakibatkan terjadinya pernikahan dini karena tidak adanya kegiatan positif yang dilakukan anaknya

\section{Orang Tua}

Orang tua adalah komponen keluarga yang terdiri dari ibu dan bapak,merupakan hasil dari sebuah ikatan perkawinan yang sah yang dapat membentuk sebuah kelurga. Orang tua mempunyai tanggung jawab untuk mendidik, mengasuh, dan membimbing anak-anaknya untuk mencapai tahapan tertentu hingga siap untuk menjalankan kehidupan rumah tangga.

Selain faktor ekonomi dan faktor pendidikan ada juga faktor orang tua karena rendahnya pendidikan kedua orang tua sehingga pola pikir mereka pun bersifat pasrah dan menerima, kepasrahan inilah maka orang tua kurang memahami adanya peraturan dalam Undang- Undang Perkawinan No.1 Tahun 1974.

\section{Hamil di Luar Nikah}

Fenomena hamil diluar nikah saat ini sudah banyak di temui di masyarakat sekitar, karena hampir setiap hari di media TV maupun surat kabar menyajikan berita-berita mengenai seks, seperti berita pemerkosaan, penlecehan seksual, dll. Berkembangnya informasi secara cepat membuat video-video porno dapat ditonton anak remaja dengan mudah. Beredarnya penjualan video porno maupun dengan mengakses di internet secara mudah didapatkan anak remaja sekarang. Apabila anak tidak mempunyai bekal kecerdasan emosional, maka anak akan merasa penasaran dan anak akan mencoba hal-hal baru seperti contohnya hubungan seks diluar nikah. Kurangnya kasih sayang dan perhatian dalam keluarga juga menjadi salah satu penyebab anak terjerumus dalam seks diluar nikah. Anak

remaja yang membutuhkan kasih sayang dan perhatian, apabila tidak ditopang dengan keluarga yang harmonis maka anak akan mudah melampiaskan dengan melakukan perbuatan yang di langgar oleh norma dan agama, seperti hubungan seks di luar nikah.

Adapula faktor karena orang yang sudah hamil diluar nikah yang terpaksa harus dinikahkan untuk menghinndari aib keluarga mereka, walaupun masih di bawah umur tetap dinikahkan karena anak perempuannya yang 
terlanjur hamil duluan. Selain itu gaya hidup dan perilaku seks yang bebas mempercepat peningkatan kejadian kehamilan pada remaja, hal ini disebabkan oleh cepatnya pertembuhan dan perkembangan remaja yang dirangsang olehh banyaknya media yang mempertontonkan kehidupan seks.

\section{Faktor ekonomi}

Masalah ekonomi pada keluarga sering kali mendorong orang tua untukcepat-cepat menikahkan anaknya, karena orang tua yang tidak mampu membiayai hidup dan sekolah terkadang membuat anak memutuskan untuk menikah di usia dini dengan alasan beban ekonomi keluarga jadi berkurang dan dapat membantu perekonomian keluarga, karena menurut orang tua anak perempuan yang sudah menikah menjadi tanggung jawab suaminya $\mathrm{Hal}$ tersebut sering banyak di jumpai di pedesaan tetapi sekarang ini banyak juga di perkotaan, tanpa peduli usia anaknya yang belum menginjak usia dewasa, orang tua hanya mengizinkan saja karena untuk meringankan beban keluarga.

\section{Dampak Pernikahan Dini bagi para pelaku}

Setiap kejadian pasti memiliki dampak terhadap sesuatu, baik positif maupun negatif, begitu juga dengan terjadinya pernikahan dini, akan memiliki dampak secara langsung terhadap pelakunya. M Ridwan (2008: 8) mengemukakan, bahwa untuk membangun harmonisasi harus paham antara hak dan kewajiban masing-masing dan untuk mengetahui itu semua harus dibutuhkan bimbingan agama yang menjelaskan batsbats hak serta kewajiban dengan adil dan bijaksana. Jika semua suami istri menepati kewajibannya, tentu akan tertunaikan pula hak dengan sendirinya. Apabila suami telah memenuhi kewajiban terhadap istri dengan sebaikbaiknya, maka hak istri telah tertunaikan. Demikian juga apabila istri telah menunaikan kewajibannya terhadap suami, hak suami pun telah tertunaikan Terlepas dari prokontra pernikahan dini disadari ataupun tidak pernikahan dini bisa memberi dampak yang negatif, di antaranya:

\section{Dari segi pendidikan}

Jika seseorang yang melangsungkan pernikahan ketika baru lulus SMP atau SMA, tentu keinginannya untuk melanjutkan sekolah lagi atau menempuh pendidikan yang lebih tinggi tidak akan tercapai. Hal tersebut dapat terjadi karena motivasi belajar yang dimiliki seseorang tersebut akan mulai mengendur karena banyaknya tugas yang harus mereka lakukan setelah menikah (Teguh Hidayatul Rachmat, 2017: 20), atau juga karena malu dengan status barunya. Sehingga anak tersebut putus sekolah, sebagaiamana yang terjadi di desa Matanair, tempat tinggal penulis, sebut saja si Ana dipaksa menikah dengan laki-laki yang juga belum lulus SMA, lalu mereka berdua putus sekolah, pernikahannya disebabkan karena factor ekonomi.

\section{Dari segi kesehatan}

Perempuan yang menikah di usia dini memiliki banyak risiko, sekalipun ia sudah mengalami menstruasi atau haid. Ada dua dampak medis yang ditimbulkan oleh pernikahan di usia dini yakni dampak pada kandungan dan kebidanannya. Penyakit kandungan yang banyak diderita wanita yang menikah di usia dini, antara lain : infeksi pada kandungan dan kanker mulut Rahim. Hal ini terjadi karena terjadinya peralihan sel anak-anak ke sel dewasa yang terlalu cepat. Wanita yang hamil di bawah usia 19 tahun dapat beresiko pada kematian, rentan terjadi pendarahan, keguguran, hamil anggur, dan hamil premature di masa kehamilan (Teguh Hidayatul Rachmat, 2017: 21). Hal ini pernah terjadi pada Anak yang bernama Dely (Matanair) yang menikah disaat dia masih duduk di bangku kelas X MA, kemudian dia hamil dan mengalami pendarahan, disebabkan oleh rahimnya yang belum siap dibuahi, dan ketakutan dia akan rasa sakit. 


\section{Dari segi Psikologi}

Menurut para psikolog, ditinjau dari sisi social, pernikahan anak dapat mengurangi harmonisasi keluarga, hal ini disebabkan oleh emosi yang labil, gejolak darah muda, dan cara pikir yang belum matang (Teguh Hidayatul Rachmat, 2017: 22).

Bila dianalisis dampak negatif pernikahan dini lebih banyak dari pada damapak positifnya.untuk itu perlu adanya komitmen dari pemerintah dalam menekan angka pernikahan dini di Indonesia. Pernikahan dini bisa menurunkan Sumber Daya Manusia Indonesia karena terputusnya mereka untuk memeroleh pendidikan. Alhasil, kemiskinan semakin banyak dan beban Negara juga semakin menumpuk. Oleh karena itu usaha yang tepat adalah pemerintah mencanangkan program wajib belajar 12 tahun dengan syarat pemberian bantuan dan biaya gratis bagi siswa kurang mampu.

\section{Penutup}

Tujuan dilakukan pernikahan adalah memperoleh kebahagian, tentuna kesiapan yang menjadi dasar awal harus diperhatikan. Keluarga bisa dikatakan hidup bahagia apabila kebutuhan hidup dasar dapat terpenuhi. Pernikahan dini di Madura yang dilakukan oleh salah satu pasangan yang memiliki usia di bawah umur yang biasanya di bawah 17 tahun. Baik pria atau wanita jika belum cukup umur (17 Tahun) jika melangsungkan pernikahan dapat dikatakan sebagai pernikahan usia dini. Pernikahan dini pada remaja pada dasarnya berdampak pada segi fisik maupun biologis remaja, remaja yang hamil akan lebih mudah menderita anemia selagi hamil dan melahirkan, salah satu penyebab tingginya kematian ibu dan bayi. Kehilangan kesempatan mengecap pendidikan yang lebih tinggi. Disamping itu juga memiliki dampak psikologis bagi pelakunya.

\section{Daftar Pustaka}

Badan Statistik Kabupaten Sumenep Tahun 2018

Fuadudin, 1999. Pengasuhan Anak Dalam Keluarga Islam, Jakarta: Lembaga Kajian Agama dan Jender.

Kurniawati, Netty Dyah., Rachmad, Teguh Hidayatul.,Yuriadi. $2017 \quad$ Fenomena pernikahan dini di Madura. Malang : AE Publishing.

Nuroniyah, Wasman Wardah. 2011. Hukum Perkawinan Islam di indonesia, Yogyakarta: Teras.

Ridwan, M. Fuad, 2008, Membina Keluarga Harmonis, Yogyakarta: Tuju Publisher Undang-Undang No. 1 Tahun 1974 tentang Perkawinan.

Subulah, Umi \& Jannah, Faridatul. (2012). "Pernikahan Dini dna Implikaisnya Terhadap Kehidupan Keluarga Pada Masyarakat Madura (Perspektif Hukum dan Gender)" Jurnal Kesetraan dan Keadilan Gender, Volume Vii No 1.

Sulaiman. 2012. "Dominasi Tradisi Dalam Perkawinan Di Bawah Umur". Jurnal "Analisa” Vol. 19 Nomor 1 